\title{
Strategic Interaction in Tax Policies Among States
}

\author{
Rubén Hernández-Murillo
}

I $\mathrm{n}$ this paper we test for strategic interaction among U.S. states in the determination of tax rates on capital income. We find that states have a positively sloped reaction function to the tax policies of rival states when tax rates are chosen simultaneously. We also identify that a state's size has a positive effect on local tax rates.

A large literature in public economics is devoted to the study of competition among governments. The problem is interesting because competition among public agents-governments-differs importantly from many aspects of what we know about competition among private agents - consumers or firms - both in terms of equilibrium allocations and welfare outcomes. Underlying this problem are the effects of competition on governments' behavior and its normative implications, in particular how it affects the size of governments and the allocation of public funds for the provision of public goods.

Examples of competition in tax policies among governments include the following: competition for mobile capital, or tax competition; competition for mobile shoppers, or commodity tax competition; and competition for mobile firms. These examples are characterized by the mobility of the tax base in response to tax differentials among jurisdictions. In the presence of this phenomenon, a state government's choice of tax instruments is crucial for the determination of stable sources of revenues.

Competition among governmental bodies can also take many forms. For example, it can be horizontal: among states within a federation, among independent countries, or among regions within an economic union. It can also be vertical: between local and state governments or between state and federal governments.

As motivation for the empirical analysis, we focus on the literature on tax competition, reviewed recently by Wilson (1999). In this framework, governments determine tax rates on capital. The

Rubén Hernández-Murillo is an economist at the Federal Reserve Bank of St. Louis. Deborah Roisman provided research assistance.

(C) 2003, The Federal Reserve Bank of St. Louis.

equilibrium net rate of return on capital income determines the configuration of the mobile resource, the capital stock, among the jurisdictions. Revenues from capital taxation are used to finance local public goods. In the standard model there is a large number of jurisdictions, which are unable to affect the net rate of return on capital. Thus there is no strategic interaction among governments. Mintz and Tulkens (1986) and Wildasin (1988) first analyzed competition among a small number of jurisdictions. ${ }^{1}$ Allowing for a small number of jurisdictions gives individual governments the ability to affect the net rate of return by exercising market power, and strategic considerations are important-as in oligopolistic competition among firms.

In all these cases, the prevailing equilibrium in tax rates results in an underprovision of public goods because jurisdictions set tax rates that are inefficiently low in an attempt to retain their tax base. This occurs because, when one jurisdiction raises its tax rate, it generates a positive fiscal externality on its rivals (by expanding their tax base with businesses or individuals fleeing the high-tax jurisdiction). Early studies examine the features of the equilibrium among identical jurisdictions. When asymmetries are introduced, usually in terms of jurisdiction size (e.g., Bucovetsky, 1991, and Wilson, 1991), larger jurisdictions are found to set higher taxes in equilibrium (e.g., Kanbur and Keen, 1993), but smaller jurisdictions are found to enjoy higher welfare. This effect is interpreted as reflecting the market power of large jurisdictions because they control a larger share of the aggregate tax base (e.g., Hoyt, 1992).

In this paper we test for strategic competition among state governments. That is, we examine interaction among a relatively small number of

\footnotetext{
1 General conditions guaranteeing uniqueness and existence of the equilibrium in these models were established only recently, for example, by Laussel and LeBreton (1998) in the symmetric two-region game and by Peralta and van Ypersele (2002) in the asymmetric case with an arbitrary number of locations. The equilibrium of the model with specific functional forms is, however, explicitly derived in Bucovetsky (1991).
} 
competing states, which are presumed to be able to affect the determination of the net rate of return on capital income.

The empirical literature, in its approach to the models of strategic interaction, estimates the reaction function of tax policies - the rule that individual states follow in choosing their tax rate, taking as given the configuration of tax rates chosen by its relevant competitors. The goal of such an approach is, as in this paper, to account for the effects from the interaction of neighboring governments, or relevant rivals, in the determination of policies. We identify neighboring states in terms of geographic and economic distance.

Identifying strategic interaction, or the ability of individual governments to affect the net rate of return on capital income, has important implications for the properties of the equilibrium configuration of tax rates among rival states: In particular, changes in the tax rate of one of the states, triggered by exogenous factors in that state, will imply cascading ramifications into other states' tax rates if there is strategic interaction.

This literature borrows from the spatial econometrics literature (see Anselin, 1988, for an introduction). One of the first studies is that of Case, Rosen, and Hines (1993), in which the authors test for spatial interaction in the determination of state expenditures. Besley and Case (1995) study strategic interaction in tax policies among states in a model where voters evaluate the performance of incumbent politicians using the taxing behavior of other jurisdictions as a benchmark, or yardstick. Brueckner (1998) analyzes the determination of growth control policies for cities in California. More recently, Saavedra (2000) applies the standard model of tax competition to the case of welfare benefits, Brueckner and Saavedra (2001) investigate property-tax competition among local governments in the Boston metropolitan area, and Fredriksson and Millimet (2002) examine the determination of environmental policies in the United States (see also Levinson, 1999a,b). ${ }^{2}$

A study closely related to ours is Buettner (2001), which analyzes the strategic determination of tax rates on capital income using a panel of municipalities in Germany. Buettner finds strong evidence of strategic interaction. Other studies that investigate strategic interaction among the continental United States include Case, Rosen, and Hines

2 For a comprehensive review of recent empirical studies, see Brueckner (2003)
(1993), Besley and Case (1995), and Fredriksson, List, and Millimet (2002).

We estimate the reaction function for the determination of tax rates on capital income with yearly panel data using the methodology of instrumental variables, which is computationally simpler than alternative methods. ${ }^{3}$

In the following section we present the econometric model and the reaction function that is estimated. We then examine the data and comment on our estimation results. Finally, we provide some concluding remarks and discuss avenues for future research.

\section{ECONOMETRIC MODEL}

Tax-competition models predict the following: When tax rates are chosen strategically, the reaction function reflects the response of the representative jurisdiction to the policies set by its neighbors, because the mobility of the tax base - the capital stock, for example-depends on the policies of all the rival jurisdictions.

The model we estimate posits that a state's tax rate depends on the neighboring states' tax rates and on a set of local socioeconomic variables:

$$
t_{i t}=\rho \Sigma_{j \neq i} \omega_{i j} t_{j t}+x_{i t}^{\prime} \beta+u_{i t} .
$$

Since we use a cross-section of states over time, the subscripts $i$ and $t$ represent states and time periods, respectively; $\rho$ is a scalar parameter measuring the slope of the reaction function; $\omega_{i j}$ are spatial weights used to compute the effect of the tax rates of the relevant competitors of state $i ; \omega_{i j} \neq 0$ if states $i$ and $j$ are rivals, and, by convention, $\omega_{i i}=0$; finally, $x_{i t}$ is a vector of state $i$ 's socioeconomic conditions, and $\beta$ is the corresponding vector of coefficients. We assume that the parameters $\rho$ and $\beta$ are constant across time periods and cross-section units. In vector form, the model is given by

$$
t_{t}=\rho W t_{t}+X_{t} \beta+u_{t}
$$

where $t_{t}=\left(t_{1}, \ldots, t_{N t}\right)^{\prime}$ is the $(N \times 1)$ vector of state policies for the cross-section of $N$ states at time $t, W$ is an $(N \times N)$ matrix of spatial weights, and $X_{t}$ is an $N \times K$ matrix with rows given by the set of vectors $x_{i t}^{\prime} ; u_{t}$ is the corresponding $(N \times 1)$ error term vector. This functional form can be derived, for example, from the theoretical model of Peralta and van Ypersele (2002) with asymmetric jurisdictions.

\footnotetext{
3 We make the computer code and data available to the reader at our web site, < http://research.stlouisfed.org/publications/review/ > .
} 
The spatial weights matrix, $W$, is constructed from exogenous factors; it determines the set of relevant competitors and captures the notion of proximity among the states in the tax competition game. When the spatial weights $\omega_{i j}$ are appropriately normalized to add up to 1 , the spatial lag term, $w t_{t}$, represents the average tax rate of the rivals and the spatial autoregressive parameter (or the slope of the reaction function), $\rho$, measures the individual response of a state's own tax rate to changes in the configuration of the tax rates among its neighbors.

Many alternative weighting schemes have been used in the literature. Weights are usually assumed to be known and constant over time; but, more generally, they are chosen to reflect some notion of geographic or socioeconomic distance between jurisdictions. For example, the simplest measure of proximity gives a weight $\omega_{i j}=1$ if states $i$ and $j$ are contiguous and 0 if they are not. In this case, the weights are equal for each of the state's competitors. Another measure is based on gravity models where the weights are inversely proportional to geographic or economic distance, for example, $\omega_{i j}=1 / d_{i j}{ }^{2}$, where $d_{i j}$ is the distance in miles between state $i$ and state $j$. An example of time-variant weights assigns a weight of zero to noncontiguous states and weights each contiguous state by its population. In our analysis we examine a variety of alternative weighting schemes, both with constant and time-variant measures.

The test for strategic interaction consists of testing for the significance of the spatial autoregressive parameter, $\rho$. Alternative models of interaction among governments yield different predictions on the sign of $\rho$. A common feature of models of horizontal competition, such as tax competition for capital, is the prediction of a positive slope. (See Brueckner, 2003.) Analogous to oligopolistic models of competition among firms, the interpretation of a positive sign is that tax rates are strategic complements, as in the differentiated products case of price competition. Models of vertical interaction among different levels of government often yield a negatively sloped reaction function. This indicates that policies are strategic substitutes, as in the case of quantity competition among firms. In our case, we expect the estimated sign of $\rho$ to be positive.

Tax rates are determined endogenously in equilibrium; thus, the spatial lag term, $w t_{t}$, is correlated with the error term $u_{t}$, and ordinary leastsquares (OLS) yields inconsistent estimates of the parameters. Removing the simultaneity in model (2), the estimation can be carried out with alternative methods. The reduced form equation

$$
t_{t}=\left(I_{N}-\rho W\right)^{-1} X_{t} \beta+\left(I_{N}-\rho W\right)^{-1} u_{t},
$$

where $I_{N}$ represents an identity matrix of size $N$, is essentially the solution of the Nash equilibrium of the game.

Equation (3) can be estimated by maximum likelihood under normality assumptions. The study of Case, Rosen, and Hines (1993) was among the first to use this method. Other studies that use maximum likelihood methods are Besley and Case (1995), Brueckner (1998, 2000, 2003), Saavedra (2000), Brueckner and Saavedra (2001), and Garrett and Marsh (2002). Another alternative is the use of instrumental variables, as suggested by Kelejian and Robinson (1993) and Kelejian and Prucha (1998, 1999). Empirical studies that use this technique are Buettner (2001) and Fredriksson and Millimet (2002). These two methodologies yield consistent estimates of the parameters.

Even in the absence of spatial autoregression $(\rho=0)$, the estimation of model (2) can lead us to conclude erroneously that there is strategic interaction if the error term itself is subject to spatial autocorrelation, for example, in the form of

$$
u_{t}=\lambda W u_{t}+\varepsilon_{t}=\left(I_{N}-\lambda W\right)^{-1} \varepsilon_{t},
$$

where $\varepsilon_{t}$ is distributed with mean zero and covariance matrix $\sigma_{\varepsilon}^{2} I_{N}$. In this case, spatial dependence in the error - for example, resulting from similar geographical conditions-can induce correlation in tax rates even though states may have no strategic considerations. Uncorrected spatial correlation in the error term would not affect the unbiasedness of the estimated parameter $\beta$, but it would reduce its efficiency. If there is strategic interaction $(\rho \neq 0)$, ignoring the spatial lag term, $W t_{t}$, in the estimation is more serious, since it yields inconsistent estimates of $\beta$. (See Case, Rosen, and Hines, 1993.) It is important, therefore, to test for both kinds of spatial dependence (in the dependent variable and in the error term).

Maximum likelihood estimation is complicated when we account for spatial correlation in the error term by possible identification problems. (See Anselin, 1988.) In our application we follow the instrumental variables approach because it avoids this issue, it is computationally easier to implement, and it does not require distributional assumptions on the error term $\varepsilon$.

Since we assumed that the parameters $\gamma=\left(\beta^{\prime}, \rho\right)^{\prime}$ and $\left(\sigma_{\varepsilon}^{2}, \lambda\right)$ are time-invariant, we estimate the model pooling the panel observations, stacking observations 


\section{Table 1}

\section{Summary Statistics: 1977-99}

\begin{tabular}{lrrrr} 
Variable $^{\text {a }}$ & Mean & Mininum & Maximum & Standard deviation \\
\hline Average capital tax rate (\%) & 25.8 & 16.4 & 42.2 & 4.4 \\
Population & $5,008,300.2$ & $411,530.0$ & $33,499,204.0$ & $5,342,718.2$ \\
Population density & 366.0 & 4.2 & $10,294.9$ & $1,411.7$ \\
Percent of urban population & 67.7 & 32.2 & 100.0 & 15.1 \\
Percent unemployment & 6.2 & 2.2 & 18.0 & 1.6 \\
Per capita real personal income & $20,669.7$ & $12,309.0$ & $36,870.3$ & $3,103.5$ \\
Percent of working-age population & 52.2 & 36.5 & 72.6 & 7.6 \\
Average monthly temperature & 60.5 & 50.7 & 68.6 & 2.1
\end{tabular}

NOTE: ${ }^{a}$ Cells are averages over time of statistics computed over cross-sectional units.

${ }^{\mathrm{b}}$ In 1996 dollars.

so that the cross-section index runs faster than the time index. Stacking observations, we estimate the model:

$$
\boldsymbol{t}=\rho \boldsymbol{W t}+\boldsymbol{X} \beta+\boldsymbol{u}
$$

with

$$
\boldsymbol{u}=\lambda \boldsymbol{W u}+\varepsilon
$$

where $\boldsymbol{t}=\left(t_{1}{ }^{\prime}, \ldots, t_{T}{ }^{\prime}\right)^{\prime}$ and $\varepsilon=\left(\varepsilon_{1}{ }^{\prime}, \ldots, \varepsilon_{T}{ }^{\prime}\right)^{\prime}$ are $(N T \times 1)$ vectors, with $T$ equal to the total number of periods. $\boldsymbol{X}$ is the $(N T \times K)$ matrix of stacked exogenous variables. $\boldsymbol{W}$ is an $(N T \times N T)$ block-diagonal matrix of spatial weights, with $T$ copies of $W$ along the diagonal, in the case of time-invariant weights, and with matrices $\left(W_{1}, \ldots, W_{T}\right)$ in the case of time-variant weights. Finally, we assume that the covariance matrix of $\varepsilon$ is given by $\sigma_{\varepsilon}^{2} I_{N T}$.

When the spatial weights matrix is the same for both the spatial lag and the error autocorrelation models, as we assume, an application of Kelejian and Robinson's (1993) method of moments (GMM) estimator is outlined as follows. The covariance matrix of the error term is given by

$$
E\left(\boldsymbol{u} \boldsymbol{u}^{\prime}\right)=\Sigma_{\boldsymbol{u}}=\sigma_{\varepsilon}^{2}\left(I_{N T}-\lambda \boldsymbol{W}\right)^{-1}\left(I_{N T}-\lambda \boldsymbol{w}^{\prime}\right)^{-1} .
$$

The moments condition is the orthogonality between the set of instruments $\boldsymbol{H}$ and the error term $\boldsymbol{u}$ :

$$
E\left(\boldsymbol{H}^{\prime} \boldsymbol{u}\right)=\mathbf{0}
$$

Following Kelejian and Prucha's (1999) suggestion, we use as instruments the linearly independent columns of $(\boldsymbol{X}, \boldsymbol{W} \boldsymbol{X})$. The GMM estimator is given by

$$
\hat{\gamma}_{G M M}=\left(\boldsymbol{Z}^{\prime} \hat{\boldsymbol{D}} \boldsymbol{Z}\right)^{-1} \boldsymbol{Z}^{\prime} \hat{\boldsymbol{D}} \boldsymbol{t},
$$

where $\boldsymbol{Z}=(\boldsymbol{W} \boldsymbol{t}, \boldsymbol{X}), \hat{\boldsymbol{D}}=\boldsymbol{H}\left(\boldsymbol{H}^{\prime} \hat{\Sigma}_{\boldsymbol{u}} \boldsymbol{H}\right)^{-1} \boldsymbol{H}^{\prime}$, and $\hat{\Sigma}_{\mathfrak{u}}$ is a consistent estimate of $\Sigma_{\boldsymbol{u}} \cdot{ }^{4}$ Kelejian and Robinson (1993) show that this estimator has an asymptotic normal distribution. The asymptotic variance (used to test for the significance of the coefficients) is given by

$$
\operatorname{Asy} \operatorname{Var}\left(\hat{\gamma}_{G M M}\right)=\left(\boldsymbol{Z}^{\prime} \hat{\mathbf{D} Z}\right)^{-1} .
$$

\section{ANALYSIS}

\section{Data}

We use yearly panel data on a set of variables reflecting local geographic, demographic, and economic conditions for the contiguous 48 United States and the District of Columbia over the period 1977-99. We construct an average tax rate on capital income using the methodology of Jones (2002) and Mendoza, Razin, and Tesar (1994). ${ }^{5}$

In the usual tax competition model, the tax base in each jurisdiction is determined endogenously by the tax rates set by the competing jurisdictions. In addition, the tax base is determined by local economic and demographic conditions, which reflect the size of the tax base and the nature of the

\footnotetext{
4 To obtain a consistent estimate of $\Sigma_{\boldsymbol{u}}$, we use Kelejian and Prucha's (1999) nonlinear least-squares estimators of the error variance and autocorrelation parameters $\left(\sigma_{\varepsilon}^{2}, \lambda\right)$

5 This approach has been used for other purposes by Burnside, Eichenbaum, and Fisher (2000) and Cavallo (2002), among others.
} 
public expenses the local jurisdiction has decided to finance with tax revenues.

Table 1 presents the summary statistics of the variables used in the estimation. Among the explanatory variables, we include real income per capita and the unemployment rate to account for local economic conditions. We include population, the fraction of urban population, and the fraction of working-age population (18-64 years) to account for the characteristics of the local tax base. In addition, we also include states' average monthly temperature to account for differences in the natural attractiveness of locations.

It is important to account for the size of states, as measured by population or personal income, to identify the effect of differentials in tax base size found in the theoretical literature; as we discussed in the introduction, the size of the tax base is commonly seen as indicative of the relative taxation power of local jurisdictions.

For periods between national censuses, we used population projections (including those by age group) provided by the Bureau of the Census. Population density was computed using these estimates and the square mileage of states computed by the Bureau of the Census in 1970, 1980, and 1990, assuming the same values throughout the decade following the census year. ${ }^{6}$ We followed the same strategy with the measures of urban population. The data on real per capita personal income are from the Bureau of Economic Analysis (BEA), and the unemployment rate is from the Bureau of Labor Statistics. The data on average monthly temperature is from the National Climate Data Center.

We tried several alternatives for spatial weights. First we identified the set of rival states with a binary scheme for contiguous geographic boundaries (including states that share a common vertex). Second, as in Fredriksson and Millimet (2002), we considered neighboring states as defined by Crone (1998/1999), who updated the BEA's classification of economic regions according to common movements in indices of economic activity. The definition of relevant competitors in this case captures similarities in the composition of the states' industrial base and not merely their physical proximity. In addition to these two binary measures, we weight neighbors by

\footnotetext{
6 The square mileage of states differs only slightly among these census years. The main source of variability in density is, of course, the variability in the population.
}

three measures of economic distance: population, distance decay between the states' population centroids, and the distance decay between a set of local economic indicators. In the first case, weights are given by $\omega_{i j t}=P_{j t}$, where $P_{j t}$ is neighbor $j$ 's population in year $t$ and the set of neighbors of state $i$ is defined by one of the binary schemes described above. In the second case, the weights are given by $\omega_{i j t}=1 / d_{i j t}{ }^{2}$, where $d_{i j t}$ is the distance in miles between the population centroids of states $i$ and $j .{ }^{7}$ Finally, in the third case, we also compute weights with the Mahalanobis (1930) distance between states, using population density, average temperature, and personal income as indicators. ${ }^{8}$ In all cases, the weights matrix was row-normalized so that $\Sigma_{j \neq i} \omega_{i j t}=1$. This normalization facilitates the interpretation and makes the parameter estimates of alternative models comparable (see Anselin, 2002); it has been used, even when the weights do not follow a binary scheme, by Case, Rosen, and Hines (1993) and Brueckner and Saavedra (2001).

\section{Results}

We present the results for the average capital tax rate in Tables 2 and 3. In Table 2 we use border contiguity to indicate neighboring states. In Table 3 we use Crone's (1998/1999) definition of economic regions to define neighboring states.

All variables are measured in logs, so the coefficients are interpreted as elasticities. The first column presents the OLS estimation of the restricted model, where we set $\rho=0$ and $\lambda=0$. This model is used to compute the robust LM statistics of Anselin et al. (1996) to evaluate the presence and source of spatial autocorrelation, that is, in the dependent variable or in the error term. $L M_{\rho \lambda}$ tests the null hypothesis of no spatial dependence $(\rho=\lambda=0)$. When this statistic is significant, we also use the tests for spatial lag in the dependent variable $(\rho=0)$, $L M_{\rho}{ }^{*}$, and the test for spatial autocorrelation in the error term $(\lambda=0), L M_{\lambda}{ }^{*}$. Both of theses tests are robust to misspecification of the spatial dependence

\footnotetext{
7 The distance was computed using the Haversine formula (see Sinnott, 1984) from the geographic coordinates for the population centroids computed by the Bureau of the Census for the years 1960, 1970, 1980, and 1990 . We use the same coordinates throughout the decade following the census year.

8 The square distance between indicators $z_{i t}=\left[\right.$ PopDen $_{i t}$, Temp $\left._{i t}, I n c_{i t}\right]$ and $z_{j t}=\left[\right.$ PopDen $_{j t}$, Temp $j t$, Inc $\left.c_{j t}\right]$ is computed as $d_{i j t}{ }^{2}=\left(z_{i t}-z_{j t}\right) \Sigma_{t}{ }^{-1}\left(z_{i t}-z_{j t}\right)^{\prime}$, where $\Sigma_{t}$ is the covariance matrix computed using all the cross-section units in period $t$.
} 


\section{Table 2}

\section{Regression Results: Average Capital Tax Rate, Border Contiguity}

Dependent variable: average capital tax rate

\begin{tabular}{|c|c|c|c|c|c|}
\hline Variables $^{\mathrm{a}}$ & OLS & $\mathbf{W}_{10}$ & $W_{11}$ & $W_{12}$ & $W_{13}$ \\
\hline Constant & $\begin{array}{r}1.36642 \\
* * *(2.88)\end{array}$ & $\begin{array}{r}0.60228 \\
(1.11)\end{array}$ & $\begin{array}{r}-0.04111 \\
(0.08)\end{array}$ & $\begin{array}{r}1.31492 \\
* *(2.33)\end{array}$ & $\begin{array}{r}1.01958 \\
*(1.95)\end{array}$ \\
\hline Population & $\begin{array}{r}0.06453 \\
* * *(13.40)\end{array}$ & $\begin{array}{r}0.06824 \\
* * *(14.51)\end{array}$ & $\begin{array}{r}0.06343 \\
* * *(14.18)\end{array}$ & $\begin{array}{r}0.07440 \\
* * *(15.02)\end{array}$ & $\begin{array}{r}0.06655 \\
* * *(13.95)\end{array}$ \\
\hline $\begin{array}{l}\text { Percent of } \\
\text { urban population }\end{array}$ & $\begin{array}{r}0.02217 \\
(1.00)\end{array}$ & $\begin{array}{r}0.04490 \\
*(1.91)\end{array}$ & $\begin{array}{r}0.02131 \\
(0.94)\end{array}$ & $\begin{array}{r}-0.01191 \\
(0.49)\end{array}$ & $\begin{array}{r}0.00238 \\
(0.10)\end{array}$ \\
\hline Unemployment rate & $\begin{array}{r}-0.03044 \\
* *(2.05)\end{array}$ & $\begin{array}{l}-0.04167 \\
* * *(2.64)\end{array}$ & $\begin{array}{r}-0.03163 \\
* *(2.03)\end{array}$ & $\begin{array}{l}-0.05814 \\
* * *(3.42)\end{array}$ & $\begin{array}{r}-0.02532 \\
(1.63)\end{array}$ \\
\hline $\begin{array}{l}\text { Per capita real } \\
\text { personal income }\end{array}$ & $\begin{array}{r}0.12815 \\
* * *(3.79)\end{array}$ & $\begin{array}{r}0.05523 \\
(1.31)\end{array}$ & $\begin{array}{r}0.08720 \\
* *(2.15)\end{array}$ & $\begin{array}{r}0.08263 \\
*(1.87)\end{array}$ & $\begin{array}{r}0.04523 \\
(1.16)\end{array}$ \\
\hline $\begin{array}{l}\text { Average monthly } \\
\text { temperature }\end{array}$ & $\begin{array}{r}-0.68053 \\
* * *(21.37)\end{array}$ & $\begin{array}{l}-0.37025 \\
* * *(8.52)\end{array}$ & $\begin{array}{r}-0.40014 \\
* * *(10.01)\end{array}$ & $\begin{array}{l}-0.41866 \\
* * *(8.72)\end{array}$ & $\begin{array}{l}-0.32413 \\
* * *(7.10)\end{array}$ \\
\hline $\begin{array}{l}\text { Percent of working-age } \\
\text { population }\end{array}$ & $\begin{array}{r}0.55510 \\
* * *(4.15)\end{array}$ & $\begin{array}{r}0.10629 \\
(0.77)\end{array}$ & $\begin{array}{l}0.31355 \\
* *(2.30)\end{array}$ & $\begin{array}{r}0.08769 \\
(0.59)\end{array}$ & $\begin{array}{r}0.00012 \\
(0.00)\end{array}$ \\
\hline$\rho$ & & $\begin{array}{r}0.61029 \\
* * *(9.12)\end{array}$ & $\begin{array}{r}0.52769 \\
* * *(9.69)\end{array}$ & $\begin{array}{r}0.44188 \\
* * *(5.87)\end{array}$ & $\begin{array}{r}0.64329 \\
* * *(10.51)\end{array}$ \\
\hline$\lambda$ & & 0.40673 & 0.32533 & 0.35571 & 0.23710 \\
\hline$\sigma_{\varepsilon}^{2}$ & 0.01809 & 0.01386 & 0.01419 & 0.01532 & 0.01554 \\
\hline$L M_{\rho \lambda}$ & & $* * * 386.11$ & $* * * 287.54$ & $* * * 280.68$ & $* * * 257.84$ \\
\hline$L M_{\rho}^{*}$ & & $* * * 106.33$ & $* * * 97.29$ & $* * * 62.65$ & $* * * 120.98$ \\
\hline$L M_{\lambda}{ }^{*}$ & & *3.13 & 2.41 & 1.86 & $* * * 34.17$ \\
\hline$L M_{\rho}^{G M M}$ & & $* * * 83.26$ & $* * * 93.84$ & $* * * 34.47$ & $* * * 110.38$ \\
\hline $\mathrm{R}^{2}$ & 0.40224 & 0.55288 & 0.54206 & 0.47451 & 0.59520 \\
\hline No. of observations & 1127 & 1127 & 1127 & 1127 & 1127 \\
\hline
\end{tabular}

NOTE: ${ }^{a}$ Dependent variable and regressors in logs. Weights matrices: $\mathrm{W}_{10}=$ border contiguity, $\mathrm{W}_{11}=$ border contiguity and population weights, $\mathrm{W}_{12}=$ border contiguity and geographic distance weights, and $\mathrm{W}_{13}=$ border contiguity and Mahalanobis distance weights. Absolute value of $\mathrm{z}$ statistics are in parentheses. $* / * * / * * *$ indicate significance at 10/5/1 percent levels, respectively, using the standard normal distribution for the coefficients and the $\chi^{2}$ distribution for the LM statistics.

in the error term. ${ }^{9}$ These tests have several advantages over tests derived from maximum likelihood estimation. The obvious one is that they require estimation of only the restricted model. ${ }^{10}$

In the second and following columns we present the estimation results for the full model using the instrumental variables method of Kelejian and

\footnotetext{
9 In our case, we have assumed an autoregressive (AR) model for the error term; an alternative is the moving average (MA) specification, $u_{t}=\lambda W \varepsilon_{t}+\varepsilon_{t}$

${ }^{10}$ In addition, these tests have been shown to behave well even for small samples using Monte Carlo simulations.
}

Robinson (1993) and Kelejian and Prucha (1999). With this model we compute Saavedra's (2003) test for the presence of a spatial lag in the dependent variable, $L M_{\rho}^{G M M}$. This test also has good properties and does not require distributional assumptions on the error term.

The results for both definitions of proximity indicate that there is strategic interaction among neighboring states in the determination of capital tax rates. Furthermore, this interaction suggests a positively sloped reaction function in tax policies, as expected. In terms of elasticities, a unitless measure, 


\section{Table 3}

Regression Results: Average Capital Tax Rate, Crone's Regions

Dependent variable: average capital tax rate

\begin{tabular}{|c|c|c|c|c|c|}
\hline Variables $^{\mathrm{a}}$ & OLS & $\mathbf{W}_{20}$ & $W_{21}$ & $W_{22}$ & $\mathbf{W}_{23}$ \\
\hline Constant & $\begin{array}{r}1.36642 \\
* * *(2.88)\end{array}$ & $\begin{array}{l}-1.85057 \\
* * *(3.75)\end{array}$ & $\begin{array}{l}-2.55462 \\
* * *(5.12)\end{array}$ & $\begin{array}{r}-0.73050 \\
(1.35)\end{array}$ & $\begin{array}{l}-1.50925 \\
* * *(2.74)\end{array}$ \\
\hline Population & $\begin{array}{r}0.06453 \\
* * *(13.40)\end{array}$ & $\begin{array}{r}0.04480 \\
* * *(9.79)\end{array}$ & $\begin{array}{r}0.04981 \\
* * *(10.52)\end{array}$ & $\begin{array}{r}0.04014 \\
* * *(8.55)\end{array}$ & $\begin{array}{r}0.04529 \\
* * *(9.54)\end{array}$ \\
\hline $\begin{array}{l}\text { Percent of } \\
\text { urban population }\end{array}$ & $\begin{array}{r}0.02217 \\
(1.00)\end{array}$ & $\begin{array}{r}-0.00154 \\
(0.07)\end{array}$ & $\begin{array}{r}-0.03127 \\
(1.37)\end{array}$ & $\begin{array}{r}0.00227 \\
(0.10)\end{array}$ & $\begin{array}{r}-0.01588 \\
(0.68)\end{array}$ \\
\hline Unemployment rate & $\begin{array}{r}-0.03044 \\
* *(2.05)\end{array}$ & $\begin{array}{r}0.01587 \\
(0.99)\end{array}$ & $\begin{array}{r}0.01896 \\
(1.18)\end{array}$ & $\begin{array}{r}0.02212 \\
(1.32)\end{array}$ & $\begin{array}{r}-0.00061 \\
(0.04)\end{array}$ \\
\hline $\begin{array}{l}\text { Per capita real } \\
\text { personal income }\end{array}$ & $\begin{array}{r}0.12815 \\
* * *(3.79)\end{array}$ & $\begin{array}{r}0.33132 \\
* * *(7.78)\end{array}$ & $\begin{array}{r}0.32649 \\
* * *(7.81)\end{array}$ & $\begin{array}{r}0.27656 \\
* * *(6.49)\end{array}$ & $\begin{array}{r}0.26924 \\
* * *(6.39)\end{array}$ \\
\hline $\begin{array}{l}\text { Average monthly } \\
\text { temperature }\end{array}$ & $\begin{array}{r}-0.68053 \\
* * *(21.37)\end{array}$ & $\begin{array}{r}-0.54038 \\
* * *(16.62)\end{array}$ & $\begin{array}{r}-0.48311 \\
* * *(14.80)\end{array}$ & $\begin{array}{r}-0.52082 \\
* * *(14.59)\end{array}$ & $\begin{array}{r}-0.57077 \\
* * *(15.10)\end{array}$ \\
\hline $\begin{array}{l}\text { Percent of working-age } \\
\text { population }\end{array}$ & $\begin{array}{r}0.55510 \\
* * *(4.15)\end{array}$ & $\begin{array}{r}0.74568 \\
* * *(5.85)\end{array}$ & $\begin{array}{r}0.88353 \\
* * *(6.70)\end{array}$ & $\begin{array}{r}0.59960 \\
* * *(4.39)\end{array}$ & $\begin{array}{r}0.86781 \\
* * *(6.46)\end{array}$ \\
\hline$\rho$ & & $\begin{array}{r}0.05686 \\
* * *(5.84)\end{array}$ & $\begin{array}{r}0.05727 \\
* * *(5.97)\end{array}$ & $\begin{array}{r}0.05272 \\
* * *(5.42)\end{array}$ & $\begin{array}{r}0.04919 \\
* * *(4.94)\end{array}$ \\
\hline$\lambda$ & & 0.51804 & 0.43683 & 0.43159 & 0.41357 \\
\hline$\sigma_{\varepsilon}^{2}$ & 0.01809 & 0.01369 & 0.01388 & 0.01410 & 0.01462 \\
\hline$L M_{\rho \lambda}$ & & $* * * 400.87$ & $* * * 256.67$ & $* * * 269.27$ & $* * * 236.12$ \\
\hline$L M_{\rho}^{*}$ & & $* * 4.69$ & $* * 6.59$ & $* * * 9.52$ & $* * 4.47$ \\
\hline$L M_{\lambda}^{*}$ & & $* * * 366.64$ & $* * * 220.77$ & $* * * 218.77$ & $* * * 200.41$ \\
\hline$L M_{\rho}^{G M M}$ & & $* * * 34.1$ & $* * * 35.59$ & $* * * 29.35$ & $* * * 24.44$ \\
\hline $\mathrm{R}^{2}$ & 0.40224 & 0.46687 & 0.44396 & 0.38293 & 0.44700 \\
\hline No. of observations & 1127 & 1127 & 1127 & 1127 & 1127 \\
\hline \multicolumn{6}{|c|}{$\begin{array}{l}\text { NOTE: 'Dependent variable and regressors in logs. Weights matrices: } \mathrm{W}_{20}=\text { Crone's regions, } \mathrm{W}_{21}=\text { Crone's regions and population } \\
\text { weights, } \mathrm{W}_{22}=\text { Crone's regions and geographic distance weights, and } \mathrm{W}_{23}=\text { Crone's regions and Mahalanobis distance weights. } \\
\text { Absolute value of } \mathrm{z} \text { statistics are in parentheses. }{ }^{* * *} / * * * \text { indicate significance at } 10 / 5 / 1 \text { percent levels, respectively, using the standard } \\
\text { normal distribution for the coefficients and the } \chi^{2} \text { distribution for the } \mathrm{LM} \text { statistics. }\end{array}$} \\
\hline
\end{tabular}

the response to an increase of 10 percent in the average of its rivals' tax rates (in this case, the geometric average, since we are using logs) results in an increase of about 4.4 to 6.4 percent in a state's initial tax rate when we use border contiguity. ${ }^{11}$ The increase in a state's own tax rate in response to a 10 percent increase in the average tax rate of its neighbors is smaller, about 0.5 to 0.6 percent, if we consider economic regions. The spatial lag coeffi-

\footnotetext{
11 That is, if the state's initial tax rate was 25 percent, according to its reaction function this state will increase its tax rate to 26.1 percent, a percentage change of 4.4 percentage points.
}

cients are significant according to standard z-statistics, but also according to the LM statistics. ${ }^{12}$ The robust LM statistics computed with the OLS residuals suggest that the spatial dependent variable lag is the relevant source of spatial dependence when we use border contiguity in the spatial weights; but the tests identify spatial effects also in the error term when we use economic regions to assess proximity.

Turning to the explanatory variables, we find a positive effect of local population, indicating that

\footnotetext{
12 Since the estimators are asymptotically normally distributed, we use the standard normal probabilities to evaluate significance of the coefficients.
} 
more-populated states set higher tax rates. The elasticity is significant and is about 0.06 in the case of border contiguity and about 0.04 in the case of economic regions. Real per capita income also has a positive effect, but it is significant only when economic regions are considered; the elasticity is about seven times as large as the elasticity of population in this case. The signs of these effects are consistent with the view that larger (or richer) jurisdictions have higher market power at taxing local businesses, as is found in the theoretical models of Bucovetsky (1991), Kanbur and Keen (1993), and more recently Peralta and van Ypersele (2002).

The rate of unemployment has a statistically significant effect only in the case of border contiguity, and the effect is negative. The fraction of working-age population has a positive effect on local tax rates. These results are consistent with the positive effect of real per capita income and the size-effect interpretation. ${ }^{13}$

The degree of urbanization was not found to be significant in any of the specifications. We also included monthly average temperature as an explanatory variable to account for differences in the natural attractiveness of locations. The coefficient was found to be negatively significant; this may indicate differential effects of natural local advantages (as in north versus south) in the determination of tax policies.

In assessing the economic significance of these parameter estimates, it is important to notice that, because we have identified that there is strategic interaction, the effects of the exogenous variables will have an impact on the entire configuration of equilibrium tax rates; this is true even if they take place in only one of the competitor states, through their repercussions on the local tax rates and, subsequently, through the responses in the tax-setting behavior of the other states.

\section{CONCLUSION}

The identification of strategic interaction in models of tax competition has important implications for the analysis of the comparative statics of the equilibrium configuration of tax rates. In this paper we found evidence of strategic interaction among states in the determination of tax policies on capital income. When we examined competition among states that share common movements in

${ }^{13}$ Jones (2002) observes a positive contemporaneous correlation between output and average capital rates in the data at the national level. economic activity, the elasticity of the average tax rate of neighboring states was found to be as large as the elasticity of local economic variables such as real per capita income. The elasticity of local population was much larger.

In our investigation we did not model explicitly the source of strategic interaction between state governments. This is a limitation of the analysis in the sense that the source of interaction is not identified. We used as motivation for the analysis the traditional model of capital tax competition, but the empirical results may be consistent with other types of competition, such as yardstick competition among politicians in models of elections.

Our results are encouraging, however, because once the presence of strategic interaction is identified, the natural extension is to try to account for specific models of tax competition to analyze the normative implications of government behavior we discussed in the introduction. One possibility is to test for specific forms of the objective function of competing governments. For example, given existing arguments in the popular press and legislative efforts to curtail horizontal competition among governments in the United States, one could assess the welfare costs of competition by testing the implications of assuming that states behave as welfare maximizers or as revenue maximizers.

Finally, by making the computer code available to the reader, we expect this paper to serve also as an illustration of the method of instrumental variables. This technique is computationally simpler than maximum likelihood and allows for faster estimation of the full model even when spatial effects in the error term have the same spatial weights matrix as the spatial lag in the dependent variable.

\section{REFERENCES}

Anselin, Luc. Spatial Econometrics: Methods and Models. Dordrecht: Kluwer Academic Publishers, 1988.

"Under the Hood: Issues in the Specification and Interpretation of Spatial Regression Models." Agricultural Economics, November 2002, 27(3), pp. 247-67.

; Bera, A.K.; Florax, R. and Yoon, M.J. "Simple Diagnostic Tests for Spatial Dependence." Regional Science and Urban Economics, February 1996, 26(1), pp. 77-104.

Besley, T. and Case, A. "Incumbent Behavior: Vote-Seeking, Tax Setting, and Yardstick Competition." American Economic Review, March 1995, 85(1), pp. 25-45. 
Brueckner, Jan K. "Testing for Strategic Interactions Among Local Governments: The Case of Growth Controls." Journal of Urban Economics, November 1998, 44(3), pp. 438-67.

"A Tiebout/Tax-Competition Model." Journal of Public Economics, August 2000, 77(2), pp. 285-306.

"Strategic Interaction Among Governments: An Overview of Empirical Studies." International Regional Science Review, 2003 (forthcoming).

and Saavedra, Luz A. "Do Local Governments Engage in Strategic Property-Tax Competition?" National Tax Journal, June 2001, 54(2), pp. 203-29.

Bucovetsky, S. "Asymmetric Tax Competition." Journal of Urban Economics, September 1991, 30(2), pp. 167-81.

Buettner, Thiess. "Local Business Taxation and Competition for Capital: The Choice of the Tax Rate." Regional Science and Urban Economics, April 2001, 31(2-3), pp. 215-45.

Burnside, Craig; Eichenbaum, Martin and Fisher, Jonas D.M. "Assessing the Effects of Fiscal Shocks." NBER Working Paper No. 7459, National Bureau of Economic Research, January 2000.

Case, Anne C; Rosen, Harvey S. and Hines, James R. Jr. "Budget Spillovers and Fiscal Policy Interdependence: Evidence from the States." Journal of Public Economics, October 1993, 52(3), pp. 285-307.

Cavallo, Michele. "Government Employment and the Dynamic Effects of Fiscal Policy Shocks." Unpublished manuscript, New York University, November 2002.

Crone, Theodore M. "Using State Indexes to Define Economic Regions in the U.S.” Journal of Economic and Social Measurement, 1998/1999, 25(3-4), pp. 259-75.

Fredriksson, Per G.; List, John A. and Millimet, Daniel L. "Chasing the Smokestack: Strategic Policy-Making with Multiple Instruments." Unpublished manuscript, Southern Methodist University, 2002.

and Millimet, Daniel L. "Strategic Interaction and the Determination of Environmental Policy Across U.S. States.” Journal of Urban Economics, January 2002, 51(1), pp. 101-22.

Garrett, Thomas A. and Marsh, Thomas L. "The Revenue Impacts of Cross-Border Lottery Shopping in the Presence of Spatial Autocorrelation." Regional Science and Urban Economics, July 2002, 32(4), pp. 501-19.

Hoyt, William H. "Market Power of Large Cities and Policy Differences in Metropolitan Areas." Regional Science and Urban Economics, November 1992, 22(4), pp. 539-58.

Jones, John B. "Has Fiscal Policy Helped Stabilize the Postwar U.S. Economy?” Journal of Monetary Economics, May 2002, 49(4), pp. 709-46.

Kanbur, Ravi and Keen, Michael. “Jeux Sans Frontieres: Tax Competition and Tax Coordination When Countries Differ in Size." American Economic Review, September 1993, 83(4), pp. 877-92.

Kelejian, Harry H. and Prucha, Ingmar R. "A Generalized Spatial Two-Stage Least Squares Procedure for Estimating a Spatial Autoregressive Model with Autoregressive Disturbances." Journal of Real Estate Finance and Economics, July 1998, 17(1), pp. 99-121.

and "A Generalized Moments Estimator for the Autoregressive Parameter in a Spatial Model." International Economic Review, May 1999, 40(2), pp. 509-33.

and Robinson, D.P. "A Suggested Method of Estimation for Spatial Interdependent Models with Autocorrelated Errors, and an Application to a County Expenditure Model." Papers in Regional Science, July 1993, 72(3), pp. 297-312.

Laussel, Didier and LeBreton, Michel. "Existence of Nash Equilibria in Fiscal Competition Models." Regional Science and Urban Economics, May 1998, 28(3), pp. 283-96.

Levinson, Arik. "NIMBY Taxes Matter: The Case of State Hazardous Waste Disposal Taxes." Journal of Public Economics, October 1999a, 74(1), pp. 31-51.

"State Taxes and Interstate Hazardous Waste Shipments." American Economic Review, June 1999b, 89(3), pp. 666-77.

Mahalanobis, P.C. "On Tests and Measures of Group Divergence." Journal of the Asiatic Society of Bengal, 1930, 26, pp. 541-88.

Mendoza, Enrique G.; Razin, Assaf and Tesar, Linda L. "Effective Tax Rates in Macroeconomics: Cross-Country Estimates of Tax Rates on Factor Incomes and 
Consumption." Journal of Monetary Economics, December 1994, 34(3), pp. 297-323.

Mintz, Jack and Tulkens, Henry. "Commodity Tax Competition Between Member States of a Federation: Equilibrium and Efficiency." Journal of Public Economics, March 1986, 29(2), pp. 133-72.

Peralta, Susana and van Ypersele, Tanguy. "Capital Tax Competition Among an Arbitrary Number of Asymmetric Countries.” Discussion Paper 2002/31, CORE-UCL, 2002.

Saavedra, Luz A. "A Model of Welfare Competition with Evidence from AFDC." Journal of Urban Economics, March 2000, 47(2), pp. 248-79.

“Tests for Spatial Lag Dependence Based on
Method of Moments Estimation." Regional Science and Urban Economics, January 2003, 33(1), pp. 27-58.

Sinnott, R.W. "Virtues of the Haversine." Sky and Telescope, 1984, 68(2), pp. 159.

Wildasin, David E. "Nash Equilibria in Models of Fiscal Competition." Journal of Public Economics, March 1988, 35(2), pp. 229-40.

Wilson, John D. “Tax Competition with Interregional Differences in Factor Endowments." Regional Science and Urban Economics, November 1991, 21(3), pp. 423-51. "Theories of Tax Competition." National Tax Journal, June 1999, 52(2), pp. 269-304.

\section{Appendix}

\section{CALCULATION OF AVERAGE CAPITAL} TAX RATES

Appendix B in Jones (2002) describes his approach to calculating national average tax rates on capital income using the national income and product accounts (NIPA). We follow the same methodology and calculate average tax rates on capital income at the state level using the state analog of the variables he describes.

The average tax rate on capital income is defined, using Jones's (2002) notation, as

$$
\tau_{K}=\frac{\tau_{P} C I+C T+P T}{C I+P T},
$$

where $C I$ is capital income, $P T$ is (corporate) property state and local tax payments, and $C T$ is state corporate (income) tax payments. Capital income is defined as

$$
C I=P R I / 2+R I+C P+N I,
$$

where $P R I$ is proprietor's income, $R I$ is rents income, $C P$ is dividends, and $N I$ is net interest income. Finally, the personal income tax rate, $\tau_{P}$, is defined by

$$
\tau_{P}=\frac{F I T+S I T}{W+P R I / 2+C I},
$$

where FTI is (personal) federal income tax payments, SIT is (personal) state income tax payments, and $W$ is wages and salary income.

In our calculations, the corporate income and property tax payments were obtained from state and local government finances data from the Bureau of the Census. The variables used to compute capital income and the average personal income tax rate were obtained from the state personal income calculations of the Bureau of Economic Analysis. 